\title{
Prospects and Forecasting of Deep-Seated Oil and Gas Reservoirs of the Meso-Ceno Deposits of Azerbaijan
}

\begin{abstract}
Sultanov LA*
Laboratory "Physical characteristics of rocks of mineral fields", Azerbaijan State Oil and Industry University, Azerbaijan
\end{abstract}

*Corresponding author: Latif A Sultanov, Azerbaijan State Oil and Industry University, Baku, Azerbaijan, Email: latif.sultan@mail.ru

\section{Thesis}

Volume 4 Issue 2

Received Date: April 30, 2020

Published Date: May 29, 2020

DOI: $10.23880 /$ ppej-16000222

\section{Abstract}

Recently, in the Republic has been deploying drilling explorations from the eastern part to less studied central and western areas. In this reason, had a particular importance the generalization of the available geological and geophysical materials related to the new focus territory, the evaluation of the prospects of individual lithologic-stratigraphic complexes and the forecasting of deep-seated oil and gas reservoirs. Studies carried out in this direction are given in this paper, which describes the analysis of different petrophysical data. At the same time were re-interpreted reservoir and petrophysical properties of rocks, mesocenozoic deposits taken from the drilled exploratory wells and geological material of the areas of oil and gas bearing area, where are widely distributed deposits of the productive strata (PT-lower Pliocene).

As a result of analysis and interpretation of geological, geophysical and petrophysical date, it has been established that oil-andgas-bearing reservoirs are mainly fractured volcanogenic-sedimentary and carbonate rocks.

Keywords: Deposits; Suit; Porosity; Deep; Well; Density; Petrophysics; Gorizont; Drilling; Geophysics; Oil and Gas accumulations

\section{Thesis}

The presence of rich hydrocarbon reserves provides Azerbaijan with wide popularity and different status throughout the Transcaucasian region. At the same time, it was established that the total area of prospective oil and gas bearing land on land in Azerbaijan is 54\% of the entire territory. Promising territories cover the plain and foothill areas of the republic and are confined to the oil and gas bearing basins, which experienced intense immersion in the Mesozoic-Cenozoic time. However, despite more than a century-long history of oil and gas production in Azerbaijan, the identified promising areas and zones are not the same in terms of the degree of knowledge of hydrocarbon-containing deposits and resource estimates. So, in particular, if in the most studied Apsheron Peninsula the exploration is 2060 $\mathrm{m} / \mathrm{km}^{2}$, and in the areas of the Nizhnekurinsky Depression and the Caspian-Cuban region, respectively, 350 and $260 \mathrm{~m}$ / $\mathrm{km}^{2}$, then in the Central and western regions of the republic, in particular between the Kura and Iori and Adzhinoura region, the subsoil is practically not studied by deep drilling. Accordingly, the intelligence here is 7 and $3 \mathrm{~m} / \mathrm{km}^{2}$.

Studying the reservoir properties of rocks is one of the most important tasks in determining the prospects of oil and gas structures and calculating reserves in explored deposits. In addition, the current period of development of the oil and gas industry requires increasing efficiency and improving technological processes for the development of oil and gas fields. For this purpose, the geological and geophysical characteristics of the rocks were studied, which influenced the reservoir potential of sediments containing oil, gas and gas condensate accumulations of the Mesozoic Cenozoic age.

Many Geological exploration and Geophysical 


\section{Petroleum \& Petrochemical Engineering Journal}

assessments have been conducted recently in Azerbaijan which based on oil and gas perspective of deeper layers, scientific criterion have been prepared that can be basement for the future exploration. It was noted that main oil and gas deposits are related with South Caspian and Kura basins which exposed to intensive depression during the Mesozoic period. The quantity and numerical expression has not been reflected properly yet, despite the high perceptivity of the central part and deeper layers doesn't create suspicion in explorers.

It is known that exploration, production and assessment of potential of oil and gas deposits highly depends on the information gathered about the lithophysical characterization of strata encountered in geological profile. In this point of view the process mentioned above should be carried out in the oil and gas regions of South Caspian Basin where the mesozoic-cenozoic deposits are spread widely. In the article different geological-geochemical and physical aspects which affect the gas and collector potentials of oil and gas-condensate deposits encountered in area have been researched. Carried investigations show that, in the paleoprofiles created along the Kurdakhany-Shakh-deniz anticline in the north-west side of the field the Pliocene-Anthropogenic deposits were accumulated in small thickness from $100 \mathrm{~m}$ to $200 \mathrm{~m}$. The thickness increases in Qum island structure to $3600 \mathrm{~m}$, in Shakh-deniz to $6000 \mathrm{~m}$. In the edges of synclines the thickness of named deposits have higher numbers which is in north-west is $3000 \mathrm{~m}$ and in Shah deniz around 10000 $\mathrm{m}$.

So, without enough knowledge about the collector characteristics of the strata of the field the estimation of hydrocarbon reservoirs and the determination of concrete of production as well as change in exploration direction is impossible. Beside the geological-geophysical investigations carried in the field, the lithophysical and collector characteristics, for the determination of change in conformity along the field, the carbon contest, porosity, permeability, density, granular content and the velocity of the sonic waves of the above mentioned strata, specially lower parts of it have been investigated. Correspondingly the table has been prepared which reflects the collector characteristics of the field. Also the upper, middle and lower limits of physical characteristics of the field has been identified in the table. At the same time, the dependence of collector characteristics on each-other, on depth and on different physical aspects have been assessed [1-3].

The Kurin Depression is one of the most promising regions of Azerbaijan for oil and gas potential. Studies of the petrographic parameters of the rocks that make up their geological section remain one of the most important problems and become the focus of researchers. Despite the fact that detailed geological and geophysical work has been carried out here, samples of rocks taken from drilled exploratory wells have been analyzed, there is still a need to solve some problems. There is a need to study the influence of geological and physical factors on individual physical properties of rocks in the promising areas of the Kurinsky Depression. For this purpose, the petrophysical properties of rock samples taken from drilled wells in the areas of Muradkhanli, Zardob, Tarsdallar, Kursyange, Jafarly and others were analyzed comparatively. All discovered sediments involved in the sections of the wells were involved in the study. Deposits from the Upper Cretaceous to Quaternary are involved in well sections.

Studies have shown that the physical features of homogeneous and coeval rocks as a result of the influence of geological and physical processes change and acquire different meanings. These results were confirmed by studies at high temperatures and pressures. Given the crucial role of these parameters in the development of geophysical data, identifying tectonic disturbances and disturbance zones, determining zones of abnormal reservoir pressure, rock density and ultrasonic wave propagation velocity, the petrophysical results were comparatively analyzed.

Research confirms that whatever patterns in area do not exist. Here, the values of rock density and the propagation velocity of ultrasonic waves, depending on the depths and tectonic changes in depths, increase and vary over a wide range. The average density and propagation velocity of ultrasonic waves in sand, clay, siltstone and carbonate rocks respectively increase. An analysis of the physical properties of the rocks that participate in the geological structure of the Muradkhanli area shows that the deep-seated oil reservoirs of the area are associated with altered Upper Cretaceous rocks (porosity 11\%), carbonate deposits of the Eocene (marl and limestone - porosity - 9.6-10.9\%) and porous terrigenous rocks of the Eocene-Maykop (siltstone, sandstone - 15-19 5).

In the Caspian-Guba oil and gas region, reservoir properties of rocksamplestaken from deep-seated formations and exploited deposits and structures were investigated. The density of clayey sandstones located relatively in the upper parts was studied in dry and wet form and it was confirmed that these rocks vary over a wide range (1.94-2.36 g / $\mathrm{cm}^{3}$ ). The porosity of these rocks varies within $7-30 \%$, the propagation velocity of ultrasonic waves is $2500-3000 \mathrm{~m} / \mathrm{s}$. The density of sandy-argillite rocks varies between 1.78-2.29 $\mathrm{g} / \mathrm{cm}^{3}$ (dry), 2.68-2.98 g / $\mathrm{cm}^{3}$ (wet), porosity is $6.15-30 \%$, and the propagation velocity of ultrasonic waves -1800 $2200 \mathrm{~m} / \mathrm{s}$. However, the reservoir properties of the rocks are diverse, differ sharply in depth [4-8].

Studies show that, based on the generalizations of the 


\section{Petroleum \& Petrochemical Engineering Journal}

data of petrophysical and reservoir studies, a comparative analysis of deep-seated rocks was carried out in the South Caspian, Kurinsky depressions and the Caspian-Guba oil and gas region. From the analysis it follows that the change in the properties of the studied objects in a wide range is mainly due to the lithological heterogeneity of the complexes, the variety of rocks and tectonic conditions. In addition, there is a certain pattern between the coefficients of porosity and permeability. During the development and interpretation of petrophysical and production-geophysical data, it was found that some of the PT horizons are the most oil-and-gas-bearing physical features of rocks of the same age and the same name change as a result of geological and physical processes, leading to different results. The reservoir properties of the PT rocks were studied. A table was created reflecting their physical properties of a given area in time and space, as well as various types of geological features of reservoir rocks and the pattern of their distribution. A generalization of particle size data showed that compaction of poorly sorted terrigenous sedimentary rocks with depth negatively affects their primary reservoir properties until secondary porosity forms in them. When predicting the productivity of deepseated strata, along with the use of modern geophysical methods, it is also advisable to involve petrophysical studies of core material.

\section{References}

1. Alizade AA, Akhmedov QA, Akhmedov AM, Aliyev AK, Zeynalov MM (1966) Geology of oil and gas deposits of Azerbaijan. Academy Science, Nedra publishers, Russia, pp: 390.
2. Kerimov KM, Rakhmanov RR, Kheirov MB (2001) Oil and gas potential of the South Caspian megavolt. Baku, Azerbaijan, pp: 317.

3. Kocharli ShS (2015) Problems of oil and gas geology of Azerbaijan. Baku, Azerbaijan, pp: 278.

4. Dortman NB (1976) The physical properties of rocks and minerals. Nedra publishers, Russia, pp: 527.

5. Compilation of the catalog of reservoir properties of the Meso-Cenozoic deposits of oil and gas fields and prospective structures of Azerbaijan, report of the Research Institute of Geophysics-105-2009, Foundations of the Department of Geophysics and Geology Baku, Azerbaijan.

6. Gurbanov VSh, Sultanov LA (2015) On the oil and gas potential of the Mesozoic deposits of Azerbaijan. Bulletin of the Perm National Research Polytechnic University, Oil and gas and mining, 16: 7-13.

7. Gurbanov VSh, Sultanov LA, Abbasova GG (2014) Lithological-petrographic and reservoir properties of the Meso-Cenozoic sediments of the Caspian-Guba oil and gas region. Geophysical news of Azerbaijan 3-4(1): 10-13.

8. Gadirov VG (2014) Magmatic volcanism of the central Kura basin of Azerbaijan and its role in the accumulation of hydrocarbons. International Scientific Institute "Educatio" 201: 64.

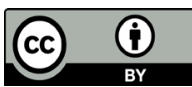

